\title{
OBITUARIES
}

\section{DR. BIMALA CHURN LAW}

The death of Dr. Bimala Churn Law on 3rd May, 1969, at the age of 77 has robbed the Society of one of its Honorary Fellows and the field of Indology of a worker of immense enthusiasm and productivity.

Dr. Law was educated at Presidency College, Calcutta, and Calcutta University, where he received the M.A., B.L., and Ph.D. degrees, being awarded the Sir Asutosh Mookerjee Gold Medal in 1924 for his research achievements. In 1931 his thesis on the history of Pâli literature was approved for the Griffith Memorial prize; it was published in two volumes in London in 1933. He gained the Litt.D. degree at Lucknow University, where he was a Bonarjee Research Prizeman. From 1916 onwards Dr. Law began to produce articles and publications on a wide range of subjects in the fields of Buddhism (including editions and translations of Pāli texts), Jainism, and the history and geography of ancient India. To describe some of these publications as compilations, as Dr. B. M. Barua did in the foreword to one of the earliest, is in no way to denigrate Dr. Law's achievement. He made his position clear when he wrote in the preface to Some Ksatriya tribes of ancient India (Calcutta, 1923), "I venture to think that I have collected all available information from the works of my predecessors, but this forms only an infinitesimal part of my work". Such borrowings, always meticulously acknowledged, served merely as a foundation upon which Dr. Law built a great structure of facts gained from very extensive reading in Sanskrit, Pāli, and Prakrit.

When, to honour his 55th birthday anniversary in 1946, a large number of his friends and admirers combined to produce a B. C. Law Volume (in two parts) of articles in his honour, the list of his own publications prefixed to it included a total of over 40 major works, besides numerous articles in periodicals. After 1946 his publications included Some Jaina canonical sütras (Bombay, 1949), Indological studies (in three volumes, Calcutta, 1950-54, comprising collected articles, both unpublished and revised), an edition and translation of the Dippavamsa (Ceylon, 1959), and translations of other Păli texts, as well as more general works on the chronicles of Ceylon and further historical and geographical works, including Geographical aspect of Kälidäsa's works and Historical geography of ancient India (both in 1954).

The Society will remember Dr. Law not merely as a scholar and a contributor to its publications series (The Magadhas in ancient India was published as R.A.S. Monograph 24 in 1946), but also as a benefactor. As a recipient of his generosity the Society is but one of many, for Dr. Law was a man of not inconsiderable wealth and a noted philanthropist who gave freely to a wide range of deserving medical, social, and academic causes. To the Society he gave the sum of $£ 1,400$ for furnishing the Reading Room when the Society moved to its present address in 1947; the Reading Room has been named the Dr. B. C. Law Room in his honour. He also endowed a trust fund in 1935 named the Dr. B. C. Law Trust Fund, for the publication of original works on (predictably) Buddhism, Jainism, or the history or geography of ancient India. The first publication under the auspices of this fund has just appeared.

Dr. Law's eminence as a scholar was recognised by the award of the degree of D.Litt. honoris causa by Allahabad University. Besides his Honorary Fellowship of the Society he was an honorary fellow or member of many other learned societies.

K. R. NORMAN. 